\title{
TRANSBOUNDARY POPULATION MOVEMENTS: REFUGEES, ENVIRONMENT AND POLITICS
}

\author{
NESRIN ALGAN - ÖZLEN KÜNÇEK
}

We are living in a shrinking world. This is the age of faster communication and transportation. It is easier to transport ideas, technological developments, daily events and financial means with a tremendous speed. Although only a small percent of the world population are the beneficiaries of the latest technological possibilities, the worldwide developments effect all the members of humankind. One of the results of globalism is an increase in the gap between haves and have-nots. Not only the faster communication and transportation means are developing but, income gaps, social conflicts, destructive weapons and local wars are also rising. Above all, the world population grew in large numbers. At the threshold of the new millennium, all these developments together with the pressure of the new wave of globalism question the role of the classical actors of international relations. As a result of conflicting themes of the new world (dis)order and the conflictual affects of the globalisation, the humankind faces major challenges interposed with these reverse trends.

Paradigms are supposed to explain the norms and patterns of a certain period of timespan. Scientists use paradigmatic explanations at their analysis. While doing this they have to use some tools. The writers of this article believe that environmental issues and refugee problem are two intertwined means among others that can be utilised to find an answer to a significant 
question: What kind of a future waits us and all the other kinds of our lonely planet at the down of the $21^{\text {st }}$ century?

The $21^{\text {st }}$ century is going to witness a larger scale transborder human movements than the previous one. Furthermore, most of these migratory movements will stem from environmental detoriation(s). Thus the twofold aims of this essay are both to underline main reasons behind the environmental detoriation, and to examine the correlation between the environment and migration movements. As the problems related to the environment are gaining weight at a global scale, so do(es) the refugee problem and the problems of refugees. Thus, in the first part of the article, the historical and conceptual backgrounds of the subject will be summarized. What is an environmental problem, how does it become international, what kind of migratory movements are there, who is a refugee and under what conditions and to what extent people are to be considered environmental refugees? These are the main questions, which we are going to try to answer in the first part of this article. At the second part of the article, different groups of related ideas and views will be analysed. The question of who are environmental refugees will take us to the question of what are the rights of refugees and specifically, of environmental refugees. It will also, bring us to an understanding that the refugee problem as a whole is a human rights problem. Related arguments will be given at the second part. At the last but not least part of the article, the main reasons that necessitate making revisions on the international conventions about the refugee problem will be evaluated.

\section{Refugee Problem: A Historical Perspective}

The history of the migratory movements is as old as the story of the humankind. The reasons behind human migration vary in a large span. It is a known fact that the ancestors of today's humankind were migrating from this piece of land to that piece in search of richer food sources by following animals and the seasons. However, these migratory movements do not fall into the scope of this study. What made migratory movements significant was the creation of territorial boundaries between different human societies. Differences between the societies or sometimes within a particular society force people to migrate to lands other than their 
own. Factors such as being a member of a religious group other than the rulers' of a definite territory was one of the earliest reasons that has traditionally forced people to migrate. Threatened and/or persecuted people have sought refuge from other territories as groups or as individuals. Huguenots were the first example in Europe who were, few centuries later, to be followed by the Jews. Nevertheless, it was not only the religious but, also, political factors that forced people to leave their homelands. Furthermore, economic factors have also been instrumental in leading people to migrate to new and foreign lands. Hundreds of thousands of poor population of Europe flowed into America. During and after the First World War, there were millions of refugees and displaced people throughout the world. Russians fleeing their home country after the Bolshevik Revolution was the first biggest group of refugees spurring the European policy-makers to develop some methods to solve the problem. The Second World War broke out before the statesmen and the decision-makers of the related international organizations finished their works with the refugees. New waves of refugees shook the world once again.

The refugee problem was one of the most important problems that the United Nations Organization (UN) had to deal with just after its establishment. The worldwide refugee problem had to be solved urgently. According to the policy-makers of the day refugee problem, to a large extent, was stemming from the war and it was also, a temporary problem. The concrete result of this way of looking at the issue was the enactment of the 1951 Convention on the Status of Refugees (the Convention). The Convention gave the first internationally recognized definition of refugee. Second paragraph of the Article 1 of the Convention states that the term refugee shall apply to any person who:

As a result of events occurring before 1 January 1951 and owing to well-founded fear of being persecuted for reasons of race, religion, nationality, membership of a particular social group or political opinion, is outside the country of his nationality and is unable, or owing to such fear, is unwilling to avail himself of the protection of that country; or who, not having a nationality and being outside the country of his formal habitual residence as a result of such events, is unable or, owing to such fear, is unwilling to return to it.

It is possible to argue that the Western countries gave shape to the Convention, which was a product of the first half of the Cold War era. During this period, major debates were concentrating 
around the human rights issue. Opinions of the representatives of the Western European states and the United States on the one hand, and the Eastern European states and the Soviet Union on the other, were conflicting. Finally, Eastern Block left the discussion table and the member countries of Western block prepared the final version of the Convention. The product eventually became a universal tool to be referred in terms of the definition and the international protection of refugees.

However, it was seen within a short period of time that the refugee problem was not a temporary one. There arose a need to revise the Convention. This revision came into the daylight with the 1967 Protocol Relating to the Status of Refugees (the Protocol). The Convention covered only those persons who had become refugees as a result of events occurring before 1 January 1951. However, new refugees have arisen since the Convention was adopted, and they were not falling within the scope of the Convention. In order to overcome this difficulty, participatory states took out the words '[A]s a result of events occurring before 1 January 1951 and...' and the words '....as a result of such events' from the definition of Article 1 of the Convention.

Even the changes made by The Protocol fell short in solving the problem. By the late 1970s, the refugee problem regained its importance within the general problem of worldwide migratory movements. The distinction between the refugees and the immigrants began to appear as artificial. As stated in the Convention, on the one hand, refugee was a person or a group of people who was/were forced to flee her/his/their home country due to the reasons that can be categorized as political in general. The general tendency, on the other hand, was to categorize immigrants as a group of people who are migrating whether as an individual or as a group, to reach to the better economic conditions. In another word, migratory movements were supposed to be taken place on a voluntary basis. It was also supposed that refugees were to be back to their home countries while immigrants were supposed to be back after reaching some level of financial cumulation.

There occurred two controversial developments during the 1970s related to the migration problem in general and the refugee problem in specific terms. First of all, the 1973 petroleum crisis had both direct and indirect effects on most of the migrants. 
Western European countries either decreased migration quotas or totally abandoned accepting immigrants. For instance, Germany, which was one of the biggest host countries for immigrants, stopped accepting new migrants by 1973 . There remained two ways for an immigrant to enter into Germany. The first one was through family unification, and the second was to seek asylum in the host country. It was also true for most of the Western European states. People from different parts of the world, especially from the developing countries who were seeking jobs and aiming at better economic conditions for themselves and their families, began to knock the back door: seeking asylum at one of the prosperous Western European states. Consequently, asylum applications increased in number. Although, most of the members of the world's refugee population were staying within their regions, Western European states were alarmed with this sharp increase in applications.

Rising numbers of refugees and also, rising numbers of people knocking the Western European states' doors, coincided with a turning point in the history of European unification. 1985 Schengen Treaty was one of the predecessor steps taken towards common external borders for the whole European Union member states. States party to the Schengen Treaty and the following Dublin Convention has decided on having joint (or at least harmonized) measures in the prevention of illegal migratory and/or refugee movements into their countries. This development was also considered as another major step in the fortification of Europe. Towards the end of $1980 \mathrm{~s}$, new developments occurred at international relations. New mass transborder population movements between the eastern and the western parts of Europe gained momentum with the breakdown of the communist regimes in Eastern Europe and specifically, with the breakdown of the Soviet Union. Hence, the end of the Cold War brought about a new turning point in the international migration and refugee regime(s).

Today, it is becoming more and more difficult to make a differentiation between economic migrants and refugees. As stated above, economic and political reasons have traditionally played important roles as the main factors behind human populations' transborder movements. It was a general tendency to group the factors as push and pull factors. If the economic conditions of home country or country of origin from where immigrants come 
are not good, it is accepted as a push factor. In other words, better economic conditions in the target country or the receiving country are to be considered as pull factor.

This is also true for the political conditions at the home or the sending country. Furthermore, until recently the general tendency was to evaluate economic factors seperately, which are supposed to have no relation with the political factors. Nevertheless, the thin line between these two groups of factors is getting more and more blurred. The general tendency today is to consider economic and political factors together in analysing the migratory movements as a whole, including both immigrants and refugees.

As Sadako Ogata, the UN High Commissioner for Refugees (UNHCR), states:

One of the greatest challenges of the 21 st century will be to ensure that people in every part of the world enjoy security and freedom: security from armed conflict, violence, human rights abuses and poverty; and the freedom to realize their personal potential, to participate in the governance of their country, and to express their individual and collective identity. ${ }^{1}$

Actually, Ms. Ogata gave first signs of the enlarging agenda of the UNHCR several years before the above-mentioned statement. She has stressed in a speech at the UN Conference on Environment and Development (1992) that new factors had already been added to the list of causes leading to the worldwide refugee movements. She has mentioned that '...more and more people are being forced to flee for a complex combination of reasons, linked as much to population growth, poverty, famine and environmental degradation as to mass violations of human rights, social and ethnic tensions and armed conflict.'2 Thus, she put environmental degradation before the traditional causes lying behind the refugee movements. It is true, on the one hand, that environmental degradation is one of the main causes of refugee

\footnotetext{
${ }^{1}$ United Nations High Commissioner for Refugees (UNHCR), The State of the World's Refugees, New York, Oxford University Press, 1995, p. 8.

${ }^{2}$ Statement by Sadako Ogata, the United Nations High Commissioner for Refugees, UN Conference on Environment and Development, Rio de Janeiro, 10.6.1992: <http://www.unhcr.ch/refworld/unhcr/hcspeech/10july1992.htm>, 04.10.1999.
} 
movements and, on the other hand, a refugee movement itself may '...lead to environmental destruction when large numbers of refugees and displaced persons seek sanctuary in ecologically fragile areas.' The High Commissioner stated strikingly that '...environmental degradation is not only a contributory factor to armed conflict, but also an inevitable consequence of it, so that people, who had fled the war, return home often to find their reintegration prospects blighted by the devastation resulting from the violence. ${ }^{3}$ Obviously, there are close links between protection and assistance of refugees and the search for solutions to their plight. Having noticed this fact, it seems difficult to ignore the interaction between the refugee movements and the developmental and environmental issues.

In the meantime, eligibility conditions that refugees are supposed to have according to the Convention have gained new specialities. Nowadays, flight from human rights abuses and poverty is accepted among the other factors that force people to leave their home countries. When UNHCR was created in 1951, there were 1 million refugees. Today, the worldwide refugee population is approximately 20 million. The sharp increase in refugee numbers and the diversification of the causes behind refugee movements are challenging factors for the UNHCR's mandating role. The post-Cold War era has also impacts on the UNHCR's mandate for the international protection of refugees. The international political and economic climate in which UNHCR was created has completely changed, as has the nature of the refugee problem. ${ }^{4}$ In today's turbulent world, conflicts accumulated by poverty, environmental degradation, resource scarcity and demographic pressures bring with themselves ethnic and religious tensions that may end in armed conflicts. ${ }^{5}$ Armed conflicts and human security occupy the agenda of all the related international governmental and non-governmental organizations. However, chronic hunger, growing poverty, increasing population pressures

\footnotetext{
${ }^{3}$ Ibid.

${ }^{4}$ Statement by Sadako Ogata, Round Table on Refugees; Challenge to Solidarity, New York, 9 March 1993: <http://www.unchr.ch/refworld/unhcr/ hcspeech/10may1993.htm>, 05.10.1999.

5 Statement by Sadako Ogata, Economic and Social Council, Agenda Item 16, July 1993: <http://www.unhcr.ch/refworld/unhcr/hcspeech/10sept1993.htm>, 05.10.1999.
} 
and employment problems, and widespread environmental destruction are the main silent factors behind these tragic events. As suggested by the UN Secretary-General, the wars and human rights abuses that provoke refugee movements are often rooted in longer-term social, economic and ecological processes. 'It is no coincidence that many of the largest population displacements of recent years have taken place in countries where standards of living are stagnant or declining'. ${ }^{6}$

The UNHCR is the only intergovernmental organization that functions in this subject area. And it is still the State that decides to give the refugee status to asylum-seekers or not. However, the UNHCR's role is changing and its functions are enlarging under the temporary conditions. 'At a time when large numbers of people are confronted with the horrors of ethnic cleansing, the threat of communal violence and a growing gap between their economic expectations and their standard of living, these will not be easy

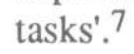

\section{New Dimensions of Environmental Politics and Security Concept}

In the 21 st century, the environmental problems are expected to maintain the level of global significance they have attained since the end of 1980s. They have not only caused fundamental deterioration of life quality for all living creatures, but have reached a level of substantial threat to their life-supporting ecosystems.

The environmental reality is being handled as a security problem by a number of scientists and decision-makers. Richard Ullman, ${ }^{8}$ an advocate of this view, argues that the actions and natural phenomena, which threaten the life quality of the citizens of a nation in a short time span, should also be handled as threats to national security. Norman Myers states in the same vein that:

${ }^{6} \mathrm{UNHCR}$, The State of the World's Refugees, p. 143.

7 Ibid, p. 9.

${ }^{8}$ R. H.Ullman, 'Redefining Security', International Security, Vol. 8, Summer 1983, pp. 129-153. 
National security is no longer about fighting forces and weaponry alone. It relates increasingly to watersheds, croplands, forests, genetic resources, climate, and other factors rarely considered by military experts and political leaders, but that taken together deserve to be viewed as equally crucial to a nation's security as military prowess. The situation is epitomized by the leader who proclaims he will not permit one square meter of national territory to be ceded to a foreign invader, while allowing hundreds of square miles of topsoil to be eroded away each year. 9

Similarly, the United Nations Development Program's 1993 Human Development Report reads:

The concept of security must change from an exclusive stress on national security to a much greater stress on people's security, from security through armaments to security through human development, from territorial security to food, employment, and environmental security. 10

When environmental problems are handled within the context of security, sustainable development and human security concepts gain a special significance. Sustainable development meets the needs of the present without compromising the ability of future generations and emphasizes the notion of inter-generation fairness. The scope of this definition alone suggests that human security does not only mean the ability to defend oneself against wars and similar armed conflicts, but also the ability to benefit from and safeguard all fundamental human rights including the right to a healthy environment.

In fact, one perceives that concepts like planet security, environmental security and human security are gradually deployed more frequently in international relations while there is also an increasing trend in the number of activities in this field in organizations such as the United Nations and its affiliates, OSCE and NATO. 'The Alliance (NATO) is commited to a broad approach to security, which recognises the importence of political,

${ }^{9}$ N. Myers, Ultimate Security; The Environmental Basis of Political Stability, Washington D. C., Island Press, 1996, p. 21.

${ }^{10}$ United Nations Development Programme (UNDP), Human Development Report, New York, Oxford University Press, 1993, p. 2. 
economic, social and environmental factors in addition to the indispensable defence dimension'. ${ }^{11}$

On the other hand, it is a common knowledge that some countries such as the USA, the Russian Federation and Canada have followed a similar approach by including these phenomena as an integral compound of the security concept in the redefinition of their national security policies and strategies. Turkey, too, adopted this new notion of security in the OSCE Military Doctrines Seminar (Vienna, 1998), during which the Chief of General Staff referred to environmental threats as one of the recent risks and threats jeopardizing the world security. ${ }^{12}$

Taking into account the mutual interaction between the humankind and its environment, preservation of the environmental resource base clearly appears as the basic factor for the realization of human security. In view of the above, it is a matter of preserving the fundamental life-supporting ecosystems that the humankind needs for survival. Therefore, the destruction of the environmental resource base evidently means the inability to sustain human life.

In fact, history teaches us that there have always been migrations from the motherland due to major environmental disasters that threaten human survival. Traditionally, peoples had been obliged to leave their habitats in cases of soil degradation due to reasons like natural disasters or over-exploitation. However, as Steve Lonegran suggests, '...more recent is the potential for mass movements caused by population growth, resource depletion and the irreversible destruction of the environment'. ${ }^{13}$

The environmental refugees problem emerges today as a product of a series of reasons including landlessness, deforestation, desertification, soil erosion, water deficits and droughts, water logging of irrigated lands and salinization, agricultural dislocation, agricultural stress, biodiversity depletion, climate change, extreme

\footnotetext{
${ }^{11}$ G. Aybet, NATO's Developing Roles in Collective Security, SAM Papers No. 4/99, Ankara, Strategic Research Center, Ministry of Foreign Affairs, 1999 , p. 89.

12 Hürriyet, 27 January 1998.

${ }^{13}$ S. Lonegran, 'Population Movements and the Environment', 1995, posted at <http://www.qen.ox.ac.uk/rsp/fmr/rpn181.htm>, 28.07.1999.
} 
weather events, population pressures, diseases and malnutrition, toxic chemicals, waste disposal, radiation and pollution problems that plague ecosystems. Stuart Leiderman, well-known environmental scientist at the University of New Hampshire and developer of the Environmental Refugees and Ecological Restoration Project, believes that:

Environmental refugees are bio-indicators of environmental quality. Today, there are refugees from floods, toxic spills and dump sites, desertification, hydro-electric projects, strip mining, radon and other radiation exposure, severe logging, soil erosion, agricultural land abuse, disease epidemics, defoliation, land mines, and other unwitting or international human activities. ${ }^{14}$

\section{Environmental Refugees: A New Category}

The term environmental refugees was first introduced by Essam El-Hihnnawi in his book Environmental Refugees published by the United Nations Environment Program in 1985. El-Hihnnawi defines environmental refugees as 'those who had to leave their habitat, temporarily or permanently, because of a potential environmental hazard or disruption in their life-supporting ecosystems. ${ }^{15}$ On the other hand, Shin-wha Lee states:

I identify environmental refugees as persons who have no choice but to leave their habitats for their very survival because of natural and human-induced ecological disasters and environmental change; or those who are internally displaced or who are compelled to cross borders as a result of harmful development plans, government ecocide, and due to the governmentís rehabilitation or resettlement plans which discriminate against specific groups. ${ }^{16}$

In literature one comes across a range of concepts such as environmental refugees, economic migrants, environmental

${ }^{14}$ N. Fell, 'Outcasts From Eden', New Scientist, Vol. 151, No. 2045, 31 August 1996, pp. 24-27:<http://gcrio.org/ASPEN/science/eoc94/EOC2>, 06.01.1999.

${ }^{15}$ E. El-Hinnawi, Environmental Refugees, Nairobi, United Nations Environment Programme (UNEP), 1985, passim.

${ }^{16}$ Shin-wha Lee, 'Emerging Threats to Post-Cold War Security: Environment, Refugees, and Conflicts,' Program on Nonviolant Sanctions and Cultural Survival, Seminar Synopses, 12 October 1994, posted at <http://data.fas.harvard.edu/cfia/pnscs/DOCS/f94lee.htm>, 08.09.1999. 
migrants, environmentally displaced persons and ecological refugees. For instance, Robert T. Strank emphasizes that main cause of this conceptual confusion may be due to the difficulty to reply the question: 'How does one identify environmental refugees as opposed to environmental migrants or conventional refugees?'17 Some common basic justifications for objecting to the concept of environmental refugees and some possible discussions in reply to this arguments may be summarized as below:

According to the some arguments, this concept does not appear in international law since international legislative regulations, such as 1951 United Nations Convention or its 1967 Protocol or 1969 African Unity Convention, neither contain any special category for environmental refugees nor refer to environmental reasons as a cause of migration. In the above mentioned article Robert T. Strank argues:

\begin{abstract}
The current parameters of the international legal definition of refugee make it inappropriate to use the term of environmental refugee in a general context. Uncritical use of the term may quickly result in confusion over what precisely is being discussed. Different users of the term may have greatly different understanding of the characteristics of the migrant, or the group of migrants to which they are referring. To avoid the legal criteria required for a bona fide refugee, it is constructive to speak of environmental migrants or environmentally displaced persons (EDP). Nor is this mere semantics. The use of these terms allows more readily for the conceptual development of environmental links with migration. 18
\end{abstract}

In fact, 1951 Convention, its 1967 Protocol and 1969 African Unity Convention do not contain any special regulation pertaining to environmental refugees. Still, one ought to relate this to the fact that these legislative documents were adopted at a time when the environmental problems had not yet reached the current level of global significance. It is more than natural to note the differences between the concrete circumstances and common problems that the world had been exposed to at the time of the drafting of 1951 Convention and now. Environmental problems, as a matter of fact, started to occupy a place in the agendas of governments and international agencies as of 1970s. Moreover, it

${ }^{17}$ R. T. Strank, 'Policy Commentary Environmental Refugees?', January 1997, posted at <http://www.dfait-maeci.gc.ca/>, 04.02.1999.

18 Ibid. 
took until the end of 1980 s, and even, early 1990 s to reach a political consensus at the global level. Eventually, towards the end of 1990s and in particular during the post-cold war era, the collective security concept began to be adopted at the political level.

In due course, the alterations in the characteristics and composition of refugees since the adoption of the 1951 Convention necessitated the initiation of analytical studies by the UNHCR. In the report drafted by the Working Group on Solution and Protection, presented on 12 August 1991 to the Forty-Second Session of the Executive Committee of the High Commissioner's Programme, persons associated with the search for asylum and refugee are handled in seven categories:

- Category 1: Persons covered by the 1951 Convention,

- Category 2: Persons covered by the OAU Convention or the Cartagena Declaration,

- Category 3: Others forced to leave or prevented from returning because of man-made disaster,

- Category 4: Persons forced to leave or prevented from returning because of natural or ecological disaster or extreme poverty,

- Category 5: Persons who apply for refugee status and are found not be in categories 1 through 4 ,

- Category 6: Internally displaced persons, and

- Category 7: Stateless persons. ${ }^{19}$

Categories 3 and 4 this study conducted by the UNHCR in view of the alterations in the characteristics of the refugees, acknowledge industrial accidents as well as natural or ecological disasters as major reasons for the transboundary movements of populations.

On the other hand, the 1994 Arab States Refugee Status Convention's definition of refugees in Paragraph 2 of Article 1

\footnotetext{
${ }^{19}$ Executive Committee of the EC/SCP/64, High Commissioner's Programme of 12 August 1991, Forty-second session (includes EC/SCP/64/Corr.1 of 12 August 1991), Report of the Working Group on Solution and Protection to the Forty-Second Session of the Executive Committee of the High Commissioner's Programme, New York, United Nations, 1991, passim.
} 
reads '...due to natural disasters or devastating incidents that consequent in a substantial degradation of public order in the whole or a part of any country.' It may be argued that this regulation has been influenced by the significance that the environmental problems have gained at the global level, and in particular by the 1992 United Nations Environment and Development Conference, commonly known as the Rio Summit.

As a matter of fact, Chapter 12, titled Managing Fragile Ecosystems: Combating Desertification and Drought of Agenda 21 , adopted by the Conference, describes one of the program areas as 'developing comprehensive drought preparedness and droughtrelief schemes, including self-help arrangements, for droughtprone areas and designing programs to cope with environmental refugees.' One of the fundamental targets listed below this heading is 'to develop drought-relief schemes and means of coping with environmental refugees and integrate them into national and regional development planning. ${ }^{20}$ Perhaps, there may be arguments advocating that Agenda 21 does not have the legally binding effect equal to that of an international convention. Despite these arguments, however, one should not underestimate the significance of this document, adopted by the heads of states and governments of 178 countries, in terms of political commitment, international common law practice and ethical values.

Consequently, the preamble of the United Nations Convention to Combat Desertification in Countries Experiencing Serious Drought and/or Desertification, Particularly in Africa that was opened to signature in 1994 with the objective of realizing these targets, mentions desertification and drought amongst the reasons for migration. The same facts also appear in two more places in the Convention; Article 10 (National Action Plans) and Article17 (Research and Development). Ultimately, this document legislatively records environmental factors as one of the possible reasons resulting in international migration. In parallel to the global level significance attached to the environmental security problematic, there will most probably be an unavoidable and gradually increasing trend to issue legislative regulations pertaining to this issue.

${ }^{20}$ The United Nations Program of Action from Rio, Earth Summit Agenda 21, New York, United Nations 1994, p. 105. 
According to some other arguments, environmental reasons frequently overlap with situations like economic migration and war. Advocates of this view, argue that usage of the term environmental causes overlap with economic reasons. For instance, the illegal migrations from Mexico, Cuba and Haiti to the USA very frequently have intertwined reasons of both economic and environmental nature. Following the same lines, Nolan Fell suggests:

There are now more people moving to the US than in its heyday of immigration, 1890 to 1910 . Then, fewer than 900,00 people entered the country in any one year. Today, illegal immigration from Mexico alone reaches 1 million a year. There is no doubt that the money and apparent opportunity in the US are irresistible lure for many. But according to figures from the Natural Heritage Institute in $S$ an Francisco, more than 60 per cent of the land in Mexico is severely degraded and soil erosion leaves 259,000 hectares of grazing and crop land -an area the size of a megacity- unproductive each year. Unsustainable farming practices and, increasingly, desertification caused by climate change drive 900,000 people off the land each year. So, are the Mexicans who cross the US border illegally at night economic migrants or environmental refugees? 21

It is almost always a very challenging and complex task to establish the link between environmental destruction and migration caused by unemployment, malnutrition and even famine due to economic problems. Moreover, the difference between environmental degradation and resource scarcity emerges as yet another major factor. The definition of environmental degradation covers all pollution-related problems including even the loss of fertile land. On the other hand, according to Stranks resource scarcity

is a broader concept than environmental degradation. Scarcity often, but not necessarily, implies some type of environmental degradation.... identifying scarcity is quite difficult. This occurs as scarcity is partly a sociological response, as given Per capita level of a commodity may be considered low by one individual or group and adequate by another. Moreover, the distribution of goods amongst different groups in society, perhaps on an ethnic basis, can contribute to scarcity in one or more of the groups. 22

\footnotetext{
${ }^{21}$ Fell, Outcasts From Eden, p. 25.

${ }^{22}$ Strank, Policy Commentary Environmental Refugees.
} 
On the other hand, a similar overlapping is observed in cases of war and other forms of armed conflicts. The extent of environmental degradation caused by wars makes it very difficult to identify whether the population migrates due to war itself or the consequent environmental degradation.

One has to admit, in most cases, it is rather challenging to differentiate between environmental refugees and economic migrants. This fact has also been tackled by Norman Myers in 1995 in his report Environmental Refugees prepared for the Climate Institute. The report indicates that:

It is often difficult, however, to differentiate between refugees driven by environmental factors and those impelled by economic problems. In certain instances, and especially as concerns cross-border refugees, people with moderate though tolerable economic circumstances at home feel drawn by opportunity for a better economic life elsewhere...Refugees are pushed from danger, whereas migrants are pulled or attracted toward more viable destinations. 23

As suggested by this description, economic migrants move to a location with the objective of finding better employment, accommodation and living conditions. In contrast, environmental refugees are obliged to abandon their homelands against their will with the priority objective of survival. Moreover, the environmental refugees, as in the case of Chernobyl nuclear plant explosion, either have no chance of returning to their homelands or are able to do so only after many years and generations. Hence, the differentiation between economic migrants and environmental refugees becomes much easier a task in cases of nuclear disasters, building of a dam, desertification and elevation of the sea level due to changes in the climatic conditions or natural disasters.

The distinguishing features between economic and environmental factors, however, overlap or even intertwine in cases of long term cumulative soil erosion or erroneous agricultural policies that deteriorate the living conditions of the rural populations who are consequently exposed to economic challenges created by environmental degradation and, thus, are obliged to

${ }^{23}$ N. Myers, Report on Environmental Refugees, Washington D.C., The Climate Institute, 1995, passim. 
migrate with the objective of finding better employment opportunities like in the example of refugees from Haiti and Mexico to the USA. Nevertheless, in most of these cases the underlying reasons of migration are completely related to the degradation of the environmental resource base. According to Myers' above mentioned report '...people who migrate because they suffer outright poverty are frequently driven by root factors of environmental degradation. ${ }^{24}$ In this context, the differentiation between economic migrants and environmental refugees gives one the impression that such practices are almost artificially created by migration receiving countries in order to justify the choice of statue recognized to the migrants rather than determining whether the underlying reason is genuinely economic or environmental. In practice, it is trivial to determine whether these people migrated because of environmental degradation or resource scarcity. As a matter of fact, resource scarcity basically emerges as a consequence of man-made or natural reasons. Hence, in majority of cases cumulative changes occur in the ecosystem. In other words, resource scarcity is ought to be considered as an integral aspect of environmental degradation. Most of the time human activities challenge the natural carrying capacity of land resources system and, thus, disturb the ecological balance so strongly that resource scarcity occurs.

World Status of Desertification Report clearly emphasizes that during recent decades, while people were the main agents of desertification, they were also its victims. According to this Report:

The mass exodus from rural areas affected by desertification that has been taking place in Africa since the late 1970 s is a vivid illustration of the plight of people facing such intolerable environmental conditions. At the peek of the crisis, in 1984 and 1985, an estimated 30-35 million people in 21 African countries were seriously affected by severe droughts, of which about 10 million were displaced and became known as environmental refugees. [...] The overall situation in areas affected by desertification, in particularly in Africa, may be illustrated by a conclusion of the most recent study in The Sudan [K. Olsson and A. Rapp, 1991]: 'The drought of 1982-1984 resulted in serious dryland degradation in Central Sudan. The period was characterized by greatly diminished rainfall, loss of vegetation, crop failures with zero harvest

${ }^{24}$ Ibid. 
of cereals, soil erosion, famine, suffering and death of people and livestock, and human migration from the region'. 25

On the other hand, Canada Department of Foreign Affairs and International Trade data illustrate that:

Drylands on every continent are being degraded. While Africa is the most severely affected region (73\% of drylands affected), desertification touches vast areas of Asia (1312 million hectares) and Americas. In fact, almost 100 countries, including 80 in the developing world are affected... Over 250 million people are directly affected by desertification, and some millions are at risk...Annual income forgone at the global level, in the areas immediately affected by desertification, is estimated at approximately US\$ 42 billion each year. One World Bank unpublished report suggests that the depletion of natural resources in one Sahelian country was equivalent to $20 \%$ of its annual Gross Domestic Product. 26

Nutrition crisis, which may occur due to reasons like deforestation and soil erosion accelerated by high population growth, leads to mass migrations in countries already suffering from politically unstable governance. One of the most evident and vivid example is the case of Ethiopia since half million Ethiopians are currently living in refugee camps in Sudan while approximately three million are displaced in the country. In this apparent case, in order of level of impact, all of demographic, environmental, economic and political reasons are present. Nonetheless, it seems rather relevant at this point to reiterate once again that those people who migrate because they suffer outright poverty are frequently driven by root factors of environmental degradation.

The most realistic of all arguments is the relation between war and migration. The world public watched live on their TVs the conventional migration experienced during the Kosova war. However unfortunately, the environmental contamination and degradation caused by war and the weaponry were the main factors

${ }^{25}$ UNCED, 'Status of Desertification and Implementation of the United Nations Plan of Action to Combat Desertification', World Status Of Desertification, Part I, 15 July 1996: <http://www.grid2.cr.usgs.gov/des/uncedp1.html>, 20.07.1999.

26'The UN Convention to Combat Desertification,' Global Agenda, Vol. 4 (2), 1996: <http://www.dfait-maeci.gc.ca/english/NEWS/NEWSLETR/GLOBAL/ glo0-2htm>, 18.08.1999. 
hindering a major number of the refugees from returning to their homelands after peace was restored.

A joint UNEP/UNCHS (Habitat) Task Force on the Balkans was formed on May 5, 1999, in order to collect, harmonize, integrate and review information on potential and real environmental (air, chemicals, hazardous waste, land, water) and human settlements (including energy demand and supply, and economic and demographic indicators) impacts of Balkan conflict. According to the reports, $40 \%$ of water resources are contaminated only in Kosova. ${ }^{27}$ Of course, it may not be very appropriate to relate the reasons keeping some Kosovars from returning home solely to environmental degradation. Detailed scientific studies, illustrating that these people have in fact become environmental refugees in neighboring countries and are not able to resettle in their homelands because of environmental contamination, are not yet available.

At this point, it may be useful to recall the experiences of the Vietnam War as an acknowledged example of similar nature. Liederman argues that:

During the Vietnam War, US forces conducted environmental warfare against the North Vietnamese, dropping defoliants and other toxic chemicals throughout the war zone. A 1982 United Nations study reported that 15,000 square kilometers of mangrove forest had been destroyed. Other researchers found that countless bomb craters not only halted farming but harbored the stagnant-water habitat necessary for mosquitoes and other disease vectors. Millions of peasants suddenly became environmental refugees. 28

On the other hand, wars that are mainly fought for the sake of dominating and possessing any natural resource do not only cause more environmental disasters but also create refugee problems since people migrate either due to the war or the consequent environmental degradation. The best acknowledged

${ }^{27}$ Balkan Task Force, Situation Report, No. 13, Thursday, 15 July 1999: <http://www.grid.unep.ch/btf/reports/report13/index.html>, 20.07.1999.

${ }^{28}$ S. M. Liederman, 'Environmental Refugees' in International Organization for Migrations and Refugee Policy Group, Encyclopedia of the Future, May 1995; and Migration and the Environment, Geneva and Washington, D.C., International Organization for Migration and Refugee Policy Group, both posted at <http://pubpages.unh.edu/ leiderman>, 04.02.1999. 
example of this was experienced during the Gulf War and in its aftermath. Again, in the same region another typical experience to this fact was observed as the practices of the Iraqi government in southern parts of the country during the period 1991- 1994. During the 1996 Annual Meeting of the American Association for the Advancement of Science (AAAS) organized on 13 February 1996 in Baltimore (Maryland, USA) a presentation titled Refugees from Environmental Warfare in Southern Iraq offered fascinating data concerning this fact.

\begin{abstract}
The marches were the largest wetland system in southwest Asia and sustained a population estimated at $350,000-500,000$. In addition to the ecocide, their destruction has caused the exodus of over 350,000 Marsh Arabs who were dependent on the marches for their livelihood and maintain a symbiotic relationship with their environment. They fled as refugees to southwest Iran or as internally displaced person... After the Gulf War, the Iraqi government began massive engineering projects to drain the marches by damming and diverting the Euphrates and Tigris rivers. The marches have been turned into salt flats, with no possibility of animal or vegetable life. ${ }^{29}$
\end{abstract}

In some cases, these immigrants did not leave their national territories and thus become migrants in their own countries. Most of the populations residing in the slum areas in the outskirts of big cities in developing countries are also considered in this category. Hence, limiting the definition of refugees to only those who have fled their countries is not sufficient.

Environmental disaster episodes are place-specific, therefore, fleeing villages, cities, districts or bioregions within countries should be sufficient. Some nations and many relief agencies now recognize the existence of these internal refugees, who may be in hiding or held captive by severe conditions. In total their numbers likle equal those who have actually crossed frontiers. 30

According to another argument, conventional refugees are defined as a matter of human rights, whereas migration due to

${ }^{29}$ S. M. Liederman, 'Learning to Recognize Environmental Refugees', Bulletin, 11-17 February 1996; and R. R. Francke, et.al., 'Refugees from Environmental Warfare in Southern Iraq', Statement presented during the 1996 Annual Meeting of the American Association for the Advancement of Science, Baltimore, Maryland, 13 February 1996, posted at <http:// pubpages.unh.edu/ leiderman>, 20.07.1999.

${ }^{30}$ Liederman, Encyclopedia of the Future. 
environmental reasons cannot be regarded as such. ${ }^{31}$ In any case, one cannot possibly agree that environmental refugees should not be regarded as a matter of human rights. Environment, in addition to development and democracy are not only basic common values of this century but will remain as such in the next century, too.

The relationship between human rights and the environment is widely recognized. As governments, intergovernmental and non-governmental organizations work towards strengthening the legal expression of a new generation of ecological rights and to progressively integrate environmental concerns into the national, regional, and international procedures aiming at the protection of human rights, new practices have evolved which portend new developments in the field of law. ${ }^{32}$

Ecological rights have been developed to their current qualitative level mostly with the help of UNESCO's renewed categorization of a specific number of human rights. The World Health Organization's 1946 Charter accepts that health is a fundamental human right regardless of race, religion, political opinion, and economic and social condition. In this context, right to environment primarily emerges as an annex to the right to health while ecological damage must be perceived as a phenomenon that threatens human health at a global scale.

UNESCO's mid-1970 third generation human rights concept contains the right to environment as well. The distinctive aspect of this group of human rights is that they all necessitate solidarity. This group is composed of:

- Right to development,

- Right to live in a peaceful and disarmed world,

- Right to a healthy and ecologically balanced environment, and

- Right to benefit from the common assets of humanity.

Solidarity rights have two fundamental common characteristics: they belong to the community as a whole and their

${ }^{31}$ Strank, Policy Commentary Environmental Refugees.

${ }^{32}$ F. Z. Ksentini, 'Human Rights, Environment, and Development', in United Nations Environment Programme, UNEP's New Way Forward: Environmental Law and Sustainable Development, Nairobi, UNEP, 1995, p. 96. 
realization depends on active participation from all social actors. ${ }^{33}$ Fatma-Zohra Ksetini argues that:

The Stockholm Declaration adopted in 1972 United Nations Human Environment Conference affirms the inextricable links that exist between environment and civil and political rights, such as the right to freedom, equality and dignity, and also between environment and economic rights, with reference to the right to live adequate conditions, and in an environment that permits a life of well-being and dignity. Underlying the links between the right to development, which is recognized as a human right by several international instruments and defined as such by the 1986 Declaration on the Right to Development, and the environment is the notion of indivisibility and interdependence of all human rights whether civil, political, economic, social or cultural. 34

The Rio Declaration adopted by the 1992 United Nations Environment and Development Conference may be regarded as a more advanced step in the context of right to environment as interpreted above. Declaration Principle 4 states that 'in order to achieve sustainable development, environmental protection shall constitute an integral part of the development process and cannot be considered in isolation from it'. Besides, Principle 3, which elaborates the right to development, indicates the equitable meeting of environmental and developmental rights of present and future generations in benefiting from this right. In any event, as discussed earlier in this paper, the concept of sustainable development by definition requires consideration of the expectations and needs of future generations. The most particular characteristic of this definition of the concept is that it is based on the notion of intergenerational fairness. In view of this approach, one may argue that currently ecological rights are no longer recognized for solely the present generations but also for future generations.

Aarhus Convention on Access to Information, Public Participation in Decision-Making and Access to Justice in Environmental Matters, regulating the access to environmental

${ }^{33}$ C. Hamamcı, 'Çevre Hakkı Ũzerine Düşünceler' (Opinions on Ecological Rights), Insan Hakları Yıllı̆̆ı, Vol. 5-6, 1983-1984, Ankara, 1985. See also J. M. Devallier, La Droit de l' Environnement, Paris, PUF, 1987 and I. Kaboğlu, Çevre Hakkı (Right to Environment), Istanbul, Iletişim Yayınları, 1991.

${ }^{34}$ F. Z. Ksentini, Human Rights, Environment, and Development, pp. 96-97. 
information and participation rights, sets the most up-to-date example of a regional convention regarding the level of progress achieved for this specific right. On the other hand, it is common knowledge that at the national level, 60 countries including Turkey have internalized the ecological rights in their Constitutions in the context of protecting the environment and natural resources. Moreover, both the European Court of Human Rights, European Commission of Human Rights and Inter-American Commission on Human Rights have issued a significant number of rulings and decisions concerning breaches of ecological rights. ${ }^{35}$

Advocating that the problem of environmental refugees cannot be considered as a human rights issue, therefore, would evidently be pointless in the face of such significant progress achieved at the national, regional and global levels regarding the recognition of ecological right as a human right.

\section{Concluding Remarks: From Concern to Crisis}

History has always recorded the mutual interaction between the environment and population. This interaction, however, has reached phenomenal proportions in connection with the environmental refugee movements only in the 20th century. Today, the irreversible damage to the environment due to major environmental disasters, rapid population growth, high levels of consumption and similar reasons have led to the global recognition of common problems affecting all countries such as deforestion, desertification, erosion and global warming. United Nations Population Fund acknowledges that '...the phenomenon derives both from population growth and environmental deterioration, leading to an extreme degree of human deprivation....Already there are at least 10 million of these environmental refugees - more than the total refugees at the end of World War II . ${ }^{36}$

In the light of all these findings regarding environmental refugees, it is possible to give two main reasons for this phenomenon: Natural Disasters and Man-made Causes. Natural

\footnotetext{
$35_{\text {Ibid., p. } 108 .}$

${ }^{36}$ United Nations Population Fund, Population, Resources and the Environment, The Critical Challenges, London, UNPF, 1991, p. 63.
} 
disasters cover floods, volcanoes, earthquakes and similar events. Man-made causes, on the other hand, cover deterioration of the natural resources and ecological balance as a consequence of human activities. One may offer a classification for these reasons as follows:

1. Deforestation, land degradation, erosion, salinity, siltation, waterlogging, climate changes, desertification emerging as a consequence of the cumulative changes or modifications caused by various forms of human activity;

2. Development policies, schemes and projects; land utilization schemes, human settlement or forced resettlement, irrigation, dam, thermal or nuclear power plant projects are well known causes for displacement; (Dr. Steve Lonergan argues that in India 20 million persons have been uprooted by development projects) $)^{37}$;

\section{Industrial and/or nuclear accidents;}

4. Conflict and warfare (Environmental degradation emerges as both the reason and consequence of conflicts. Besides armed conflict for the sake of sharing natural resources, the environment, itself is sometimes used as a weapon of war).

We know as a matter of fact that, today, at least 10 million people have become environmental refugees due to such reasons. On the other hand, many governments take little formal account of this nontraditional or unconventional category of refugees. There are number of studies today arguing that number of refugees in this category has been increasing more rapidly than in any of the other categories. They put the number of such refugees over 25 million (10 million recognized, 15 million unrecognized). 38 Meanwhile, some other studies illustrate that,

of the aggregate of 43 million of all types, three out of five being environmental refugees, 20 million are in Sub-Saharan Africa...Well

37'Population Movements and the Environment', RPN 18, January 1995, posted at <http://www.qen.ox.ac.uk/rsp/fmr/rpn181.htm>, 28.07.1999.

38'Environmental Refugees: A Crisis in the Making', People and Planet, V. 13 (4), 1994: <http://www.oneworld.org/textver/patp/pp_eco_refugees. html>, 07.11.1999. 
over 30 countries have generated more than 100,000 refugees each. Of these, 15 countries have generated at list one million refugees each or have a population where one person in ten is a refugee...Each day roughly 5,000 people find themselves obliged to abandon their homelands for environmental reasons. All this figures are expected to climb rapidly. ${ }^{39}$

Currently, poverty occupies a priority position in the list of most important human problems. Some writers argue that the 21st century will see a return to the 15 th century due to the close interaction between the environment and poverty which is considered as the major risk in the next century. This argument assumes that the continuation of the economic globalisation will have a profound impact on one billion underprivileged people in the 21 st century, leading to dramatic deterioration in the livelihood of poorer rural populations and, thus, propagating exponential growth in the migration phenomenon. ${ }^{40}$ According to the World Resources Institute, 'by 2010, malnutrition in Africa will increase 70 percent, affecting some 300 million people. Furthermore, the Population Action International (PAI) reports state that the number of nations facing chronic water shortage is projected to rise to 50 , mainly in the Middle East and Africa. ${ }^{4} 1$

Besides poverty, taking into account the growth in the worldís population, imbalances in the sharing and exploitation of natural resources and the global level of environmental problems, one may easily predict a rapid growth in the number of environmental refugees in the forthcoming period and a consequent risk of increased conflict potential due to the interacting environmentpopulation-migration factors. Studies on the potential number of refugee movements due to environmental factors, and mainly climatic changes, in the forthcoming years predict a figure as large as 150 to 200 million. For instance, Norman Myers makes the

${ }^{39}$ Ibid.

${ }^{40} \mathrm{~A}$. Agarwal, 'Le XXIe siècle fera retour sur le XVe siècle', Propos recueillis par Hervé Kempf mardi 11 mai 1999, Le Monde, Mis à jour le lundi 6 septembre 1999.

${ }^{41}$ J. Motavalli, 'Environmental Degradation Creates a New Class of Refugees', Exodus: <http://www.emagazine.com/novemberdecember_1996/1196chart3>, 06.11.1999. 
following projections in the context of Environmental Refugees in a Greenhouse-Affected World. ${ }^{42}$

\begin{tabular}{|l|c|}
\hline Country or Region & $\begin{array}{l}\text { Total of Refugees Foreseen } \\
\text { (Millions) }\end{array}$ \\
\hline Bangladesh & 15 \\
\hline Egypt & 15 \\
\hline Deltas and other coastal zones & 70 \\
\hline Agriculturally dislocated areas & 50 \\
\hline Total & $\mathbf{1 5 0}$ \\
\hline
\end{tabular}

No one can deny that El-Niño as a climatic phenomenon obliged 250.000 people to abandon their homes in Peru and generated 230.000 displaced persons in Somalia during 19971998. Since 1954, 3004 persons died in China due to wors floods, 13.8 million people were evacuated and 4.97 million houses were totally destroyed. In July 1998, floods affected $40 \%$ of the total surface of Bangladesh. ${ }^{43}$ In the world, the most populated areas are the coastlines. Only in China 30 million live on coastal areas that are more than half a meter below the sea level. ${ }^{44}$ Scenarios on the probable impacts of climatic change on economy, demography, society and the environment predict that only one meter elevation of the sea level is likely to affect a total of 5 million square kilometers of coastal zones at a global scale leading to catastrophic consequences. In such a case, some small island states will not exist anymore. Furthermore, approximately 120 million Bangladeshis will be homeless, one fifth of Egypt's habitable land will be lost, $50 \%$ of the projected populations of highly populated coastal metropolitans like Jakarta, Bombay, Karachi and Rio de Janeiro will become displaced and 40 million more environmental refugees will join the already existing ones. ${ }^{45}$ If only $0.5 \%$ of the 6 billion people on the globe are obliged to migrate due to environmental reasons caused by climatic change, we will end up with 30 million

${ }^{42}$ Myers, Ultimate Security, p. 191.

43 WFP's Global Task Force on El Niño, posted at <http://www.wfp.it/vam/elnino/intro.htm>, 28.07.1999.

${ }^{44}$ United Nations Population Fund, Population, Resources and the Environment, p. 64.

${ }^{45}$ Ibid., pp. 63-65. 
environmental refugees, and if this ratio reaches $1 \%$, then 60 million refugees will be generated.

Under the light of the above mentioned facts and evaluations, environmental refugees have become an inevitably recognized phenomenon by the academic circles, international governmental and non-governmental organisations. In other words, the problems related to environmental refugees have imposed themselves on the agenda and no organisation could have ignored its importance. The above mentioned Report prepared in 1991 by the UNHCR Working Group on Solution and Protection renumarates persons who are forced to leave because of natural or ecological and manmade disasters amongst the categories of asylum seekers and refugees.

It is a fact that, there is an interaction between environment and migratory movements. On the one hand, environmental degradation is one of the causes of migratory movements, on the other hand, all the migratory movements (internal and/or transboundary) have negative impacts on environment. As a matter of fact, the UNHCR has prepared the Interim Guidelines for Environment-Sensitive Management of Refugee Programmes. ${ }^{46}$ With these guidelines, the UNHCR have tried to specify the rules to be taken into consideration about the prevention of harmful effects of a migratory movement. Having recognized the hazardous effects of migratory movements, it is aimed that there should be a cooperation between the states and the UNHCR and other interrelated organisations before the possible environmental degradation occurs.

Nevertheless, not all the governments and international agencies have generally acknowledged the extend of environmental refugee problem. Although this problem ranks one of the most important concerns of our time, it will undoubtedly be one of the foremost human crises of the next century. While it may be true that many refugees may be reacting to environmental and population pressures, it is also equally true that they may generate

\footnotetext{
${ }^{46}$ See UNHCR, Interim Guidelines for Environment-Sensitive Management of Refugee Programmes, Geneva, United Nations, July 1994.
} 
political, legal, ethical, social, and economic problems that could lead to conflict and violence. ${ }^{47}$

Today, there is a need to develop a new understanding of security to incorporate an environmental dimension, and to adopt policy responses of the states by placing greater emphasis on collective security at the international level. New issues on the international agenda, such as environmental refugees, common security and humanitarian intervention, lie beyond the scope of established diplomacy and international politics. These are challenging subjects that require a response different in yet another sense. This response should 'emphasize cooperation rather than confrontation within the international arena. No nation can meet the challenges of global change on its own. Nor can any nation protect itself from the actions or inaction of other.' 48

A diverse range of actors including states, multilateral organizations, and transnational non-governmental organizations should involve in the solution of the contemporary problems. Like the environmental area, the environmental refugee subject has long been distinctive, in the extraordinary degree, to which transnational non-governmental organizations have been actively engaged in global affairs. Within this context, cooperation among all these actors in this area must be developed, and the catalytic and coordinating role of the United Nations and its organisations should be strengthened. In the eve of a new millenium, international politics continue to evolve, and there is an increasing need to manage transnational problems in a more humanitarian manner. This is a transitory period in which 'Öold norms are under challenge, but new ones have not yet emerged. Old ways of doing things may prove insufficient for new problems, yet new ways may be characterized by mistakes...To prepare ourselves for dealing with the future, whatever it may hold in store, we need to have a firm gasp on the past. ${ }^{49}$

47 N. Myers, 'Global Population Growth', posted at <http://www.pitt.edu/ wesnews/paperabs-html>, 20.07.1999.

48 Ibid.

${ }^{49}$ T. G. Weiss, D. P. Forsythe and R. A. Coate, The United Nations and Changing World Politics, 2nd ed., Colorado and Oxford, Westview Press, 1997, pp. 267-271. 
Finally, concepts of human security, democratization and human rights, and sustainable develoment should be incorporated and inextricably linked with the promotion and maintenance of peace and security. It is not possible to evaluate the large-scale transboundary population movements independently from above mentioned concepts. Environmental refugees consist of a new category that reflects the new facets of the contemporary international politics. Thus, while new norms are emerging, policy makers may take this as an opportunity to develop better and sufficient means to deal with the challenges of the next century. Essentially, it is the common international response, at both national and trans-national levels that will show us to which degree these normative approaches will be effective in the near future. 